\title{
Is an anarchist business organization possible? Textile firms in the industrial district of Alcoi during the Spanish Civil War (1936-39) ${ }^{1}$
}

\author{
Joaquim Cuevas Casaña (Universitat de València) \\ Lina Gálvez Muñoz (Universitat Pablo de Olavide) \\ Lluís Torró Gil (Universitat d'Alacant)
}

\begin{abstract}
During the Spanish Civil War, in the Republican side, a social revolution broke out, led by the workers and their unions ending in many places in a business collectivization process. In the city of Alcoi, the anarchist union took control over more than 100 textile family firms, going through a rationalization process which unified the production of all textile firms overcoming a previous production crisis and attending the war demand. Does the Alcoi case during the Civil War prove the possibility of a successful anarchist business organization? This article tries to understand the development of business without a capitalist organization and the role of business networks in such a development. The organizational design and the administration of the collectivization process is an example of how socialization of the property and democratization of the decision-making process in the company were not opposed with rationality and efficiency, at least during a war context.
\end{abstract}

Key words: Spanish Civil War; Business organization; industrial district; Alcoi; textile manufacture; social revolution; anarchism

Resumen: Durante la Guerra Civil Española, en el lado republicano, estalló una revolución social, liderada por los trabajadores y sus sindicatos que terminó en muchos lugares en un proceso de colectivización empresarial. En la ciudad de Alcoi, el sindicato anarquista tomó el control de más de 100 empresas textiles familiares, pasando por un proceso de racionalización que unificó la producción de todas las empresas textiles para superar una crisis de producción anterior y atender la demanda de guerra. ¿El caso de Alcoi durante la Guerra Civil demuestra la posibilidad de una organización empresarial anarquista exitosa? Este artículo trata de comprender el desarrollo de los negocios sin una organización capitalista y el papel de las redes empresariales en tal desarrollo. El diseño organizativo y la administración del proceso de colectivización es un ejemplo de cómo la socialización de la propiedad y la democratización del proceso de toma de decisiones en la empresa no se opusieron con racionalidad y eficiencia, al menos durante un contexto de guerra.

Palabras clave: Guerra Civil española; organización empresarial; distrito industrial; Alcoi; industria textil; revolución social; anarquismo.

\footnotetext{
${ }^{1}$ This text was presented in preliminary versions at various international conferences between 2006 and 2008 . The version that is now published dates from 2009 and has only been subjected to a slight bibliographic update of the references included at that time.
} 
After General Franco's military coup in July 1936, a part of Spain that roughly corresponded with the less industrialized area in the country succumbed to Franco's forces and a Fascist Authoritarian regime was instituted. The rest of the territory stayed loyal to the democratically elected Republican government, and it was there that, at the same time the Civil War was being fought, a social revolution broke out, led by the workers and their unions -except in the Basque Country-, in a revolutionary process against private property. In the industrial district of Alcoi, workers took control over the factories of the three main industrial sectors: textile, paper and metal. Some of the entrepreneurs escaped but most of them stayed in their factories as part of the technical committees but deprived of their executive power, which de facto passed on to the unions. In the textile sector, in addition to having control over more than one hundred family firms, the anarchist union went through a rationalization process which unified the production of all textile firms. The definite step towards a greater integration was made in September 1936, when the Union confiscated the Employers' Association and unified the whole industry as in one single firm.

Although the aim was political -to make a revolution-, collectivizations were tinted with economic justifications pointing to rationalization and the attainment of economies of scale ${ }^{2}$. Bank employees and clerks belonging to the Union were called to manage the increasing bureaucratic demands of the unification, and benefits were employed in rising wages, improving working conditions and incrementing savings. In Alcoi, the unification helped to solve the crisis the Spanish textile sector had suffered during the early 1930s. In fact, the crisis of the textile industry in the years previous to the Civil War, which coincided with the 1930s international economic crisis, was resolved in two ways. First, through the captive and constant demand that the orders of blankets and uniforms for the Republican army constituted, and second, through the revolutionary process: the collectivization and unification of the whole textile industry coordinated by the anarchist Sindicato del Textil (Textile Union). Absolutely all business functions were centralized during the war as in one big firm. Both circumstances, the captive demand and the centralized organization, explain the fact that the economic performance of the Union in 1939 improved that of the independent companies in 1936. Once the war concluded, the General Direction of Refunds, established by Franco's regime, designed a system that helped the former owners to recover their confiscated properties and the benefits obtained during the war by the anarchist union within what could be considered a successful anarchist business organization.

Beyond the fact that the former owners received the benefits and their properties back, the achievements of the anarchist business organization were never acknowledged. This must be related, on the one hand, with the repression against the working classes instituted by Franco's victorious army. In fact, the payback to the former owners happened in an institutional framework of repression against the losers, banning of labor unions and declining living conditions for the working classes. On the other hand, it must be related with the development of industrial relations in Alcoi as part of an industrialization process where capital and labor were confronted, especially during certain periods of technological change regarding the control

\footnotetext{
${ }^{2}$ Nevertheless, it is necessary to understand this process as a political action designed to win the war, unless big integrated companies are considered the natural and suitable result of capitalist development in order to attain greater efficiency.
} 
and sharing of the benefits. This caused a rise in the cost of living, particularly in the years previous to the Civil War, associated with a decrease in sales and, as a matter of fact, in the volume of labor available.

This confrontation proved very creative in organizational terms both for the employers and the workers, who developed important associations. The workers saw their unions dismantled after the war by law and repression, while the employers increased their cooperation without achieving full property integration -something that the anarchist union had during the war-, and continued working within a business network characteristic of many industrial districts as that of Alcoi. This increasing cooperation between textile firms must be understood within a new institutional context, Franco's corporatist regime, for which political influences and relations were more important than competitiveness in order to guarantee their business success, and, as a matter of fact, for small and medium family firms as Alcoi's textile firms, cooperation proved to be a useful strategy. But we could also understand this reality in terms of continuity of the cooperation activity before the war and of the successful cooperative experience conducted by the anarchist union during the war, which achieved a full integration of the whole industry. This study case raises a few questions regarding the role of authority and hierarchy versus cooperation and network development in business organization, the evolution of shared benefits between capital and labor and the function of technical and organizational changes. Other aspects such as trustworthiness as an example of escape from the market, institutional change and business survival will be addressed.

Does the Alcoi case during the Civil War prove the possibility of a successful anarchist business organization? An anarchist business organization may seem itself a contradiction since anarchist ideology claims for the lack of authority and hierarchy. However, an anarchist union achieved a business organization in textile Alcoi firms during the Spanish Civil War, in 1936-1939, which made it possible to overcome a previous production crisis and to attend the war demand. Collectivization and the employees' management of the firms only lasted during the war years since the Republican government was defeated in 1939. As a matter of fact, it is not possible to know if the workers' management could have continued to be successful without a war scenario and for a longer period. Workers had the technical know-how and even the organizational know-how, partly from their previous experience in participating in business committees as established by the Republican law in the first half of the 1930s, and partly because of the hiring of bank employees already mentioned. However, they did not have any marketing know-how, which was especially important in such a competitive sector as the textile one. During the war, this was not a problem since the market was captive and coincident with the Republican army's demand. In addition, the political goal of making a social revolution was subsidiary to a more important goal, that of winning the war. Furthermore, all that happened within the special conditions of the industrial district was subordinated to that goal. The network framework characteristic of industrial districts was essential to explain both the workers' managing period and the survival of the firms for more than four centuries until today. Alcoi's textile firms 
adapted to market and institutional changes through variations in the degree on which network coordination was integrated ${ }^{3}$.

In fact, in order to answer the question on whether an anarchist business organization was possible and to understand the process, the nature of the industrial district and the Civil War process must be both taken into consideration. This article is divided into two main parts. The first one presents the industrial district of Alcoi as an example of business network where both employers and employees faced industrialization changes by associating themselves in order to fight or to cooperate for productivity gains. The second one deals with the collectivization process and the business organization of Alcoi's textile firms within the revolutionary process developed in the territories under Republican control during the Spanish Civil War.

\section{Alcoi's industrial district: business network and industrial relationships}

The origin of the textile activities in the city of Alcoi dates back to the $15^{\text {th }}$ and $16^{\text {th }}$ centuries. In 1560 the Gremio de Peraires (Guild of Clothiers) was created and Alcoi has represented one of the most important wool textile centers in Spain ever since, after Sabadell in Catalonia. Two other industrial sectors were important in the region of Alcoi although both gravitated around the textile sector: metal and paper. This sectorial diversification, together with the prevalence of phase industries in the textile sector and the extension of the secondary activities to neighbor villages, allows to speak of a genuine industrial district ${ }^{4}$.

\section{Geographical Location of Alcoi's Industrial District}

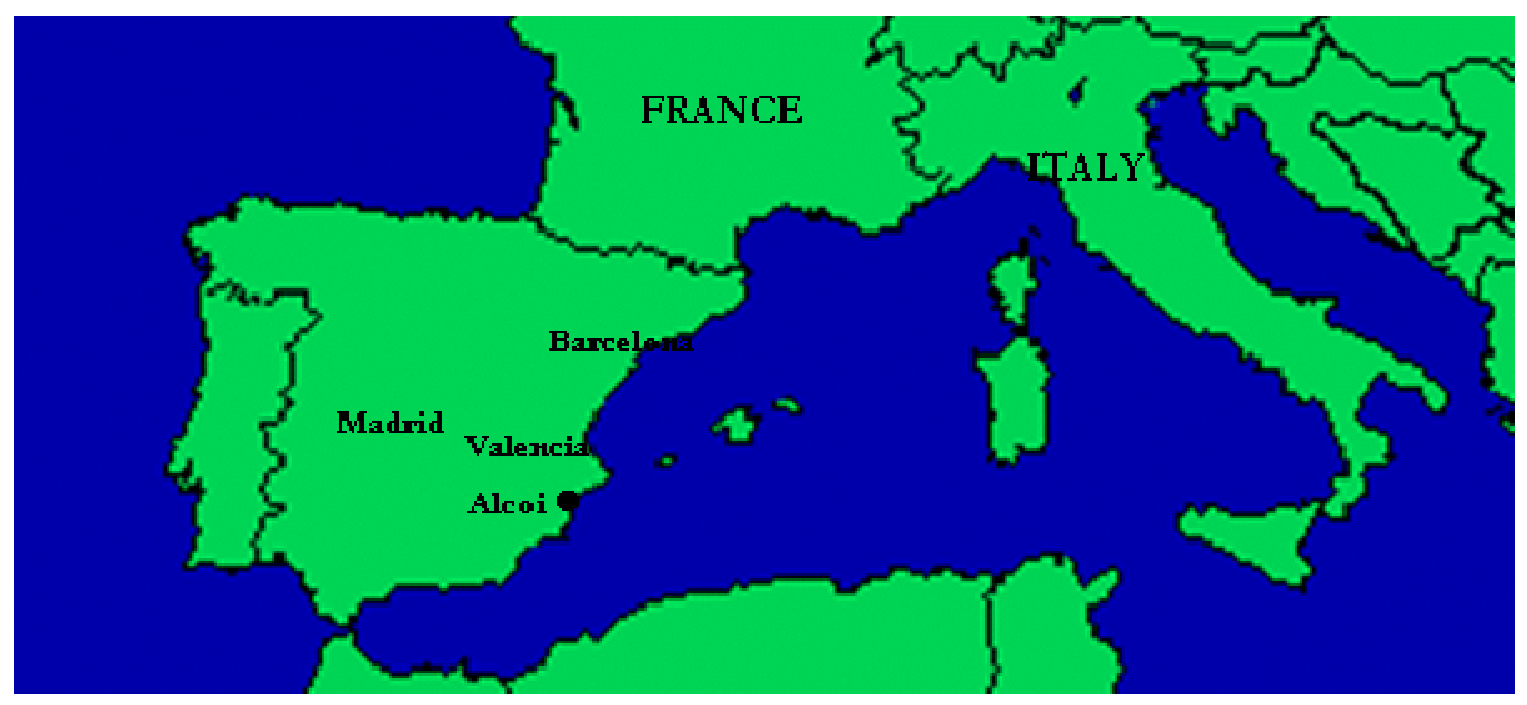

The main characteristic of the modern Alcoi textile sector was the maintenance of an atomized business structure, more typical of the first industrialization stage than of the second (Such,

\footnotetext{
3 The differences in the degree of firm integration were established according to Robertson and Langlois (1995) as the combination between the degree of property integration and the degree of coordination integration, on which a Chandlerian company represents the maximum while a Marshallian district stands for the minimum.

${ }^{4}$ On definitions and features of the Italian industrial districts: Becattini (1987); Becattini \& Rullani (1996); Piore \& Sabel (1990). See also Wilson and Popp (2003) for the United Kingdom and Scranton (2006) for North-America.
} 
1993). Concentration was difficult to achieve because of the firms' family typology, which prioritized the reproduction of the family business over the effectiveness and financial gains of their activities 5 . Domestic labor developed specific labor relations between independent weavers and employers hiring their work, generating fewer benefits per unit than it was the case for their competitors. As a matter of fact, Alcoi's textile firms during the second half of the $19^{\text {th }}$ century and the first half of the $20^{\text {th }}$ specialized in the production of low cost articles which required less investment than otherwise.

Alcoi's textile sector was not distinguished for its innovation achievements and suffered from technological backwardness. The explanation is twofold: on the one hand, the existence of a permanent labor opposition, which preferred a short-term confrontation to cooperation in favoring technological change and sharing productivity gains. The progressive push of the mechanization process ran parallel to the curve of the workers' claims and conquests, which reached its peak in the years around the 1868 revolution and the 1873 labor revolt ${ }^{6}$. From a long term perspective it is possible to convene that Alcoi's textile sector grew upon its old bases up to its own production frontier. A stronger business initiative -if that was at all possible for a region far from the main urban markets and not well connected with the main transport networks (Vidal, 1991)-, as in the Catalonian case, would have been characterized by: 1) technological change (steam and electricity), 2) access to bigger markets (associated with the interaction with other sectors and their knowledge of foreign markets), 3) greater productivity, including smaller labor costs. In fact, one of the main characteristics of the Alcoi case is that labor costs had a greater share in final costs than they had for their competitors. This became an even greater problem after the First World War, due, on the one hand, to an important and combative union movement and, on the other, to the employers' risk aversion towards major investments in innovation and opening new markets. Although this second reason was at least as important as the first one, employers just referred to the strong labor movement and to high wages when they had to justify their lack of competitiveness.

Summing up, the market's division and the sector's structure, the entrepreneurs' proximity and knowledge, together with the external threats, resulted in a scarcely horizontally integrated business structure, and fostered cooperative agreements between the firms and the creation of the Employers' Association. In fact, this network could be included in Mark Casson's typology and defined as a network characterized by trust linkages between different companies with different productive and technical levels (Casson, 1997: 815). Cooperative behaviour between employers creating a business network was a key aspect in their survival over the centuries and it explains the successful story of an anarchist business organization during the Civil War, since the employers had developed an association where certain aspects regarding institutional relations, markets and technology were commonly addressed.

\footnotetext{
${ }^{5}$ Important literature on family firms and business: Colli (2002a, 2002b); Colli, Pérez and Rose, (2003); Colli and Rose (2008); Jones and Ros, (1993). The Alcoi case from a business history perspective: Cuevas (1999, 2002).

6 Industrial transformations led to a heavy process of social polarization and the appearance of a working class that suffered from precarious life conditions and was particularly well organized and combative (Cerdà, 1980, 1996). Friedrich Engels wrote widely on these events. Until the outbreak of the Civil War, the Alcoi labor movement was mainly anarchist-oriented (Valero \& Beneito, 1996b).
} 


\subsection{The business network}

The business organization in Alcoi can be better understood within the concept of network, a network which has survived through its capacity of adaptation to changing economic and institutional conditions. A network is defined as an organizational form that agrees with the conditions of the environment and requires certain characteristics of internal consistency to allow its own efficiency (Jarillo, 1988; López, Montes, \& Vázquez, 2004: 70) ${ }^{7}$. Although coordination can also be effected through firms and markets, networks emerge quite naturally as coordinating mechanisms. It has been said that networks are preferable to markets because they involve more social contact and encourage information to be shared. Preferences regarding firm, market or network must be seen using the principle according to which the most efficient arrangement will survive and the less efficient arrangements will not. As Casson (2009) affirms, in economics networks are not the question but the answer to the question of how to improve the performance of the economy.

However, what is efficient in one place, sector or moment in time may not be efficient in another, since technological or institutional conditions may provoke the decline of a successful network. The survival of one network is, accordingly, very much determined by its capacity to adapt itself. In fact, the development of networks does not take place in a homogeneous/lineal way along the different stages of business creation and development. The treatment given in literature to the evolution of communities is related to the life cycle of the firm but not to the adaptation capacity of the firm's network in front of external shocks such as a revolution, a war, or a regime and institutional context change. The case of the textile companies in Alcoi in the previous and later years to the Spanish Civil War of 1936-1939 allows to analyze the entrepreneurs' networks in a dynamic way beyond the firms' life cycle, and to contribute to theoretical creation.

The origin of the textile employers' organization in the city of Alcoi dates back to the $15^{\text {th }}$ and $16^{\text {th }}$ Centuries. In 1560 the Guild of Clothiers was created. Later on, it was denominated Fábrica de Paños (Clothing Factory), and in 1731 it was given the title of Real Fábrica de Paños de Alcoi (RFPA, Royal Clothing Factory of Alcoi), thus becoming an official supplier of the Royal Armies. During the industrialization process of the $19^{\text {th }}$ Century -by that time Alcoi's industry grew and was mechanized, becoming one of the most competitive industrial centers in Spain-, the RFPA became a real employers' association. This association contained most of Alcoi's textile entrepreneurs behaving in a cooperative manner in order to efficiently face their common problems. During the $18^{\text {th }}$ Century, besides controlling the specialized labor as a basis for the standardization of production, the RFPA had been very active as a lobby (regarding taxconcessions, for example), as well as in the diffusion of new technologies and in the productive

\footnotetext{
${ }^{7}$ For Casson, an adequate definition of a network must be sufficiently general to accommodate the diversity noted above, yet specific enough to form the basis for rigorous analysis. The network is then defined as a set of high-trust relationships which either directly or indirectly link together all individuals in a social group. A linkage is defined in terms of individual flow between two people (Casson, 1997:813). See Thomson (2003) for the different ways social and economic historians have used the term network, and Casson (2009) for the different network typologies.
} 
transformation that took place in the last years of the $18^{\text {th }}$ Century and the beginning of the $19^{\text {th }}$ (Torró, 1994, 1996) ${ }^{8}$.

This cooperative agreement was further developed during the years previous to the Civil War, because of the international economic crisis and the new institutional context created by the Republican government in 1931, much more favorable than the previous governments to labor claims -we will elaborate this point in the next section. In fact, the proclamation of the Second Republic in 1931 introduced important novelties in this picture, although without reversing the signs. General problems, related with the world depression that had begun in 1929, were aggravated by several circumstances. The entrepreneurs understood that the social legislation introduced by the Republic worsened the bad situation because, according to the textile Employers' Association, they were indebted to "... giving up to the demands of a labor union of great arrogance...". The employers complained not only against the demands of a strict execution of the legislation on the part of the unions, but also against their opposition to the introduction of new machinery. Finally, the negative picture described by the Employers' Association was completed with the difficulties to export -linked with the Italian competitionand the transport problems due to the deficiency of the infrastructures 9

The RFPA abandoned its traditional denomination to be called, in the first instance, Fábrica de Paños (Clothing Factory, without any reference to the monarchy), and later on, Asociación Patronal de la Industria Textil y Factorías de Alcoi (APITFA, Employers' Association of the Textile Industry and Factories of Alcoi). In this period, and until the labor collectivization took place during the war, the Employers' Association became a more complex institution, inside of which there was a larger degree of cooperation between companies when facing the different changes in the institutional environment. The issues on which the Employers' Association acted more heavily were three: first of all, the institutional reinforcement of the organizational structure, establishing bonds with other local and national entities which pointed to a furtherreaching and more efficient action. Second, the collective administration of various services to the companies and also the technical advice to them, mainly in tax, labor and mercantile affairs. And finally, the adaptation and implementation of labor regulations, especially the creation of a Mutualidad de Accidentes de Trabajo (Labor Accident Mutual Coverage System). For all these tasks, the Employers' Association was endowed with specific organs -General Board, Executive Board, specific sections for every textile activity, Special Commissions- and specific staff was as well hired for the daily administration. As the balance sheets show, the organization

\footnotetext{
${ }^{8}$ In this later aspect, the activity of the Employers' Association in recruiting technicians, Spaniards or foreigners, in order to teach the members of the association new technical and productive ways to improve the quality of the final output, deserves to be remarked. It was an extended practice of the RFPA during the whole $19^{\text {th }}$ century. In this respect, there is a great example that took place in 1828: with the support of the City Council the first industrial training school was created (Gálvez \& Cuevas, 2001), the origin of the future Industrial School of Alcoi, nowadays High Technical University. This step was decisive if we consider that the competitiveness of local networks lies in their capacity to promote innovation through collective learning and to exchange information and knowledge between specialized producers, thus helping to reduce transaction costs. Also, in this case, the network played an important role in synthesizing information.
}

${ }^{9}$ Archive of the Textil Alcoyana, S. A. (onwards ATA), 9.40, Informe sobre las causas de la crisis en la industria de paños de Alcoy, s.d 
was financed by its partners, according to their tax rate; half of the budget expenditure was spent in the staff's wages ${ }^{10}$.

The second of these features constitutes the best example of the cooperative behavior among the members of the Employers' Association, since until the Spanish Civil War broke out the most important activities of the Association were focused on technical consultancy and the defense of collective business interests. The increasing demand of labor advice from the companies was at the basis of the decision to open, in 1933, a Consulting Office in charge of a Secretary Advisor, for "the associate gentlemen to be conveniently advised on their doubts about the interpretation of tariffs, wages, and the legislation of social issues". One year later this office was transformed into a Mercantile Consulting Office, managed by two mercantile expertises, and eventually supported by a Technical Consulting Committee. The issues these organizations dealt with were, generally, the accounting and organizational aspects of the firms, advice in tax matters including the presentation of all kinds of documents before the Treasury- and technical questions. Also, the Association participated, on behalf of the textile companies, in the collective bargaining with the electric power supplier, in order to reduce the rates and to assure a regular supply of electric power. Furthermore, as it had already done through the $19^{\text {th }}$ century, the Association carried out an intense data collection and systematization work for the elaboration of technical reports on the sector, to support its presence and pressure before the Ministry of Industry and Trade.

These advances in cooperation and collective management were essential to understand the anarchist success during the war once the Union took control over the Employers' Association in September 1936. In fact, this picture -characterized by a greater integration of cooperation into the business network without integrating the property- suffered a radical change when the war started. The institutional crash of 1936-1939 propitiated a new experience, collectivization, which brought the integration of property and a unified administration. All of this finished with General Franco's victory in the war, in 1939. As it is possible to see in Figure 1, this integration continued and increased after the war ended.

As we will develop in section 2.3., under the new regime established by Franco the business network showed a high degree of integration and coordination -without any property integration. The foundation of Textil Alcoyana S.A. (A.T. Alcoi Textile Limited) thus proves it (Terol, 2000). It became a basic network structure which centralized part of the managerial functions of the associated firms and was specialized in supplying consulting services to the companies. Nowadays, the association still works as a services company for more than 600 firms. When the war ended, it was also an institutional change which made businessmen react with a higher degree of coordination: the traumatic experience of collectivization served to agglutinate the interests of most firms. Franco's corporatist regulation specified that all unions and employers' associations would have to integrate into one organization, a monopolistic union. In 1940, the Alcoi Employers' Association became a limited company in order to keep

\footnotetext{
10 The Employers' Association was also very active in reinforcing relations with similar organizations, all of them belonging to the Spanish Confederation of Free Economic Entities and Mercantile Circles. In addition, APITFA actively participated in the Official Labor Chamber, in the Official Industry and Trade Chamber and in the Joint Committees of the textile sector. The association promoted as well an employers' federation for all the industrial activities in the city - The Alcoi Industrial and Trade Federation.
} 
control over the firms and -only partially- over the assets of the association. This way, Franco's interventionism on the inputs market encouraged managers to integrate into their management some processes they had previously neglected and which the unions, in the collectivization period during the war, had paid attention to.

Figure 1. Degree of property integration and coordination of the textile companies in Alcoi (Preindustrial times - 2007)

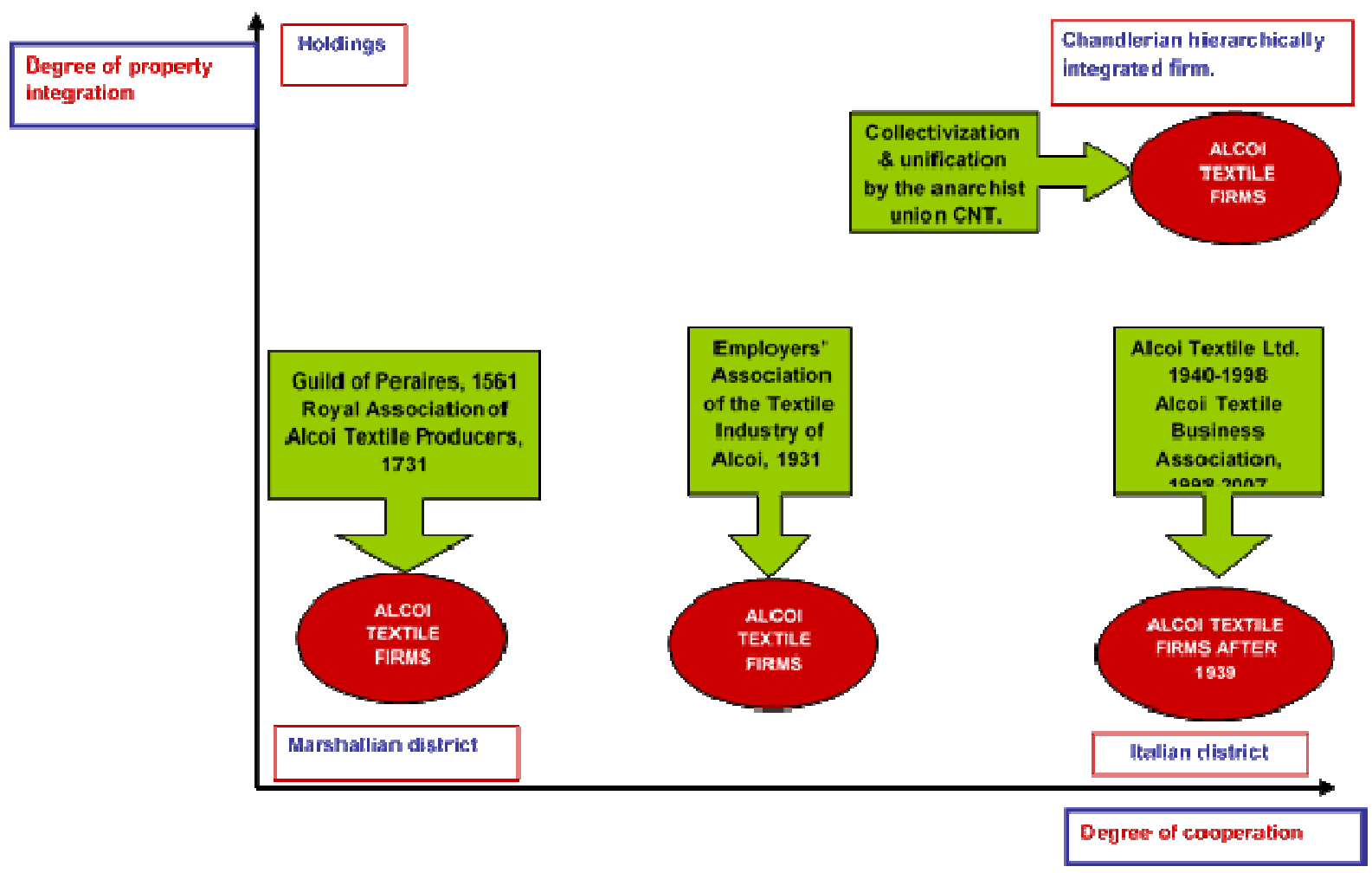

Source: Own elaboration, based on Robertson and Langlois (1995) and López, Montes and Vázquez (2004).

\subsection{Industrial relations}

During the first third of the 20th Century a double phenomenon took place in the industrial district. On the one hand, the technical and market conditions changed with a negative effect especially for those industrial districts on which companies prevailed that were not very integrated and centralized, as was the case of Alcoi. On the other hand, this situation, particularly serious after World War I and during the 1930s international crisis, was compatible with a greater degree of cooperation between the producers in order to collectively face 
structural problems. The acceleration of the mechanization process -lesser than in other competitive areas ${ }^{11}$ - was probably also accompanied by a strong resurgence, from the beginning of the 20th century, of the labor movement. Tough competition and production surplus in a market featured by a weak demand were -in the entrepreneurs' opinion - the reasons for this situation ${ }^{12}$. The special scenario originated by Spain's neutrality during World War I was marked by a strong increase of production, impelled by the export. The demand of blankets and wool uniforms for the armies in Europe during the first years and, from 1916 onwards, the import substitution were the key factors of the recovery. We must as well take into account the growing social tension that ended up causing up to six strikes in a single year, with a resulting five months-long interruption of the industrial production (Oliver, 1931). As it happened in other places, the end of the war period meant a return to normality, that is to say, the folding back to a weak and limited interior market. In short, during the first third of the 20th century the textile companies and businessmen had an increasingly organized and specialized tool to face the working class threat. It is reasonable to underline that this fact conditioned the defensive character of the employers' strategy during the first decades of the 20th century, in contrast to what had been their previous manner. In 1916 the social objective of the renewed employers' organization was very clear:

... to offer the union of all the wool-producers in this city, for the protection and defense of all their moral and material interests and for the study and implementation of reforms and modifications aiming at the improvement of production and labor... to defend and to protect the associates' rights and interests against whatever abuse or inappropriate pretence of the labor element; to be opposed to labor unions formed to achieve reforms that are considered harmful to the establishment... intervening, solving and settling the differences and conflicts between employers and workers.... to defend the interests related with the wool industry in all their branches and aspects, cooperating to increase its development and progress...13

In fact, industrial relations were not easy in Alcoi. They shared some of the common characteristics of Spanish industrial relations and some particularities related to Alcoi's business structure: the degree of its employers' risk aversion and its specialization in low cost articles where investments in innovation and technology were not considered a priority. Although Spanish industrial relations were diverse according to the sector and the different regions and, as in other countries, they evolved during the course of the industrialization process, they were characterized by a later development of labor legislation and social expenditure than in other European countries, and by a lack of cooperation and a strong confrontation between employers and workers due to the technological backwardness which did not foster an agreement of the two parts as to share productivity gains and social peace. The reduced domestic market, marked by a low income per capita and a high degree of inequality, needs to be considered as well when analyzing this trend.

\footnotetext{
${ }^{11}$ For textile, see Benaul (1994) and for paper industries Gutiérrez-Poch (1994).

12 This was the general picture in all industrial sectors and especially in the most important one in the city (Benaul \& Calvet, 2004; Gutiérrez-Poch, 1994).

${ }^{13}$ ATA, Reglamento de la RFPA, 1916.
} 
The development of modern industrial relations and institutions in Spain started at the end of the $19^{\text {th }}$ century but was especially relevant during the first third of the $20^{\text {th }}$ century, the proclamation of the Republican regime in 1931 being a turning point. Spain's previous backwardness in labor legislation shifted so that before the end of the Civil War, the Republican government had the ILO's world record of agreements signed (Gálvez, 2006b). The institutionalization of labor relations was a consequence of international trends and of the labor movement's important development. The UGT -the socialist union- was founded in 1888 and the CNT -the anarchist union- in 1910. Although the unionization rate was never high in Spain during the first third of the $20^{\text {th }}$ century -around $25 \%$ - while the division within the labor movement was indeed considerable, the development of important labor conflicts, especially strikes, was not hindered. This must be related to the revolutionary character of many unions that pursued a revolution and not a short-term improvement of the labor conditions, but also with the intransigent attitude of the employers and the government towards the labor movement and with the slow development of social expenditure.

Public intervention in labor relations accelerated after the social conflicts of the inflationary years around World War I and the triumph of the Russian Revolution in 1917, seeing the creation of a Labor Ministry in 1921. However, a dictatorial regime was established in 1923 and, consequently, all progress in labor legislation during the 1920s helped to institutionalize and legalize the positions of the employers' associations and not the workers' preferences. The Comités Paritarios (Joint Committees), created in 1926 in order to solve industrial relations unrest within the firms, were in the hands of the employers. These committees were substituted by the Jurados Mixtos (Mixed Juries) in 1931 after the proclamation of the Republic, which developed labor legislation favorable to the labor. These Juries were in charge, in each firm, of determining the general working conditions, wages, contract duration, working hours, firing conditions and all questions regarding both individual and collective contracts. Participation in these institutions was essential to understand the know-how acquired by many workers in the development of the companies they belonged to, and which was later on used by them during the collectivization process, as it happened in Alcoi.

In Alcoi, an important labor movement developed during the $19^{\text {th }}$ century. The industry's special characteristics regarding technological backwardness and the size of the firms explained the strength of the skilled workers. The major consequence of this strength was the fact that wages or -more important- labor costs were relatively higher in Alcoi than in other Spanish wool production centers such as Sabadell in Catalonia.

The changes in the organization of the production process in the textile factories are quite well known in the Anglo-Saxon world and in France, although it is almost exclusively the cotton sector and the spinning sub-sector that have been studied (Cohen, 1985; Huberman, 1996; Lazonick, 1979, 1990; Reddy, 1984). The transition from proto-industrial to completely industrial forms in cotton-producing Manchester happened through a long, complicated and at times conflictive process. The main results of this process were the masculinization of the labor force and the articulation of a subcontracting system that generated the apparition of a labor aristocracy, as Eric Hobsbawm named it (1964, 1984). English entrepreneurs were able to introduce the self-acting mules against the workers' opposition, in exchange, however, to 
maintaining a system that gave out the control of the machines to the former spinners who, at the same time, hired the assistants needed to make the machines work ${ }^{14}$.

Although there are no equivalent studies for the wool sector ${ }^{15}$, the evolution must have been very similar considering the technological characteristics, almost identical in both sectors regarding the structure of the working process. The most notable differences should be found at the beginning of the mechanization process, given the wool work's older tradition, and, in relation to spinning, as well in the specific conditions of the preceding processes due to the characteristics of the raw material itself. In addition, it was the most institutionalized sector everywhere, marked by a strong guild presence that, doubtlessly, left its imprint on the original forms of labor organization during the first times of the mechanization process. These characteristics were especially evident in everything that concerned the tissues, as it is as well to be noted in the case of Alcoi (Cerdà, 1980).

Through some information sources contemporary to the facts considered in the present work, data are available on the organization of the working processes in the Alcoi factories. In the context of the 1930s important crisis, the textile entrepreneurs' preoccupation for what they considered excessive labor costs stimulated the elaboration of comparative studies. A report written before $1934^{16}$ compared the costs of maintaining a self-acting mule in various municipalities. The differences detected between Sabadell and Alcoi inform us on the key factors of the working process organization in the case we are studying.

Industrial entrepreneurs in Alcoi emphasized their competitive weakness in salary retributions, comparing them with those of other productive centers and, in particular, with that of Sabadell, one of its main competitors in the national territory ${ }^{17}$. Indeed, a 100-threads machine set with self-acting mules occupied 13 people in Alcoi while a 140-threads machine set only required 11 workers in Sabadell. In this circumstances, the costs in Alcoi reached 597.70 pesetas while in Sabadell they only went up to 468.50 pesetas - that is, the costs were 129.90 pesetas higher $(+27.58 \%)$. With a production which was, potentially speaking, $40 \%$ stronger than that of Sabadell, unitary costs in Alcoi could exceed those of the Catalonian town in $78.51 \%$. The key of these differences can be found in three factors: the smaller number of workers, the existence

\footnotetext{
14 This case contrasts with the facts we know about the cotton industry in Spain. The works of García Balañá (2004) show how the spinners, finally, did not reach their objective and how the introduction of the self-acting mule meant the feminization of the labor force and the absolute control of the process by the employer.

15 One proof of the lack of interest in this question shown by the researchers devoted to this sector can be appreciated in a recent collective volume edited by Giovanni Luigi Fontana and Gérard Gayot (2004).

${ }^{16}$ ATA, 9.40, Informe sobre las causas, cit.

${ }_{17}$ On the wool industry of this Catalonian town, see Benaul, Calvet and Deu (1994) and Benaul and Calvet (2004). Despite their location (almost $500 \mathrm{~km}$ distant), both towns (Alcoi and Sabadell) maintained close industrial relations, especially in what concerns the labor force (Tormo, 1996).
} 
of production incentives ${ }^{18}$ and, last but not least, lower individual salaries determined by the workers' gender and age ${ }^{19}$.

The references come from a tendentious report ordered by the Employer's Association with the clear intention of reinforcing their positions in the negotiations with the Union, and, for this reason, it has important limitations that conceal decisive questions. The most significant one is indeed related to work productivity, of which no estimate is offered. Two elements are especially relevant when it comes to analyzing this question. The first one refers to the materials produced. While Sabadell was specialized in worsted and the fabrication of nouveautés, Alcoi was focused on low cost clothes for which regenerated wool was used as raw material. This difference was against Alcoi's productivity since the processed yarn was of a lower quality and, therefore, much more difficult to work with. The second element is linked to the incentive retribution system, the plus, seemingly inexistent in Sabadell. This particularity could have, nevertheless, influenced positively the productivity of Alcoi's workers.

The absence of women in the weaving factories may thus be the decisive element to explain the higher retributions of Alcoi's workers. It is very probable that the greater industrial diversification of the town offered, according to the terminology of Hirschman (1970), exits for the feminine labor force ${ }^{20}$ that reinforced the masculinization of at least an important part of the textile manufactures, the greater and more dynamic. Or, on the contrary, the greater dynamism of the Catalonian labor market could have allowed the men to find more attractive work alternatives. In any case, the masculinization of the union-organized labor force in Alcoi's textile industry could in great measure explain the high negotiation capacity and resistance of the textile workers who, this way, forced their employers to accept working conditions that were favorable to their interests. It seems reasonable to think that the masculine workers of the textile industry in Alcoi formed one sort of labor aristocracy. Due to their number and position they owned the hegemony in the local union network and were, in fact, the ones behind the collectivization process.

\footnotetext{
18 From the beginning of the $20^{\text {th }}$ century, an incentive system called plus had been introduced in Alcoi. The first reference available on this retribution dates back to 1916: ATA, Tarifa de trabajo para el oficio de tejedores mecánicos, Alcoi. However, the employers' report does not mention anything of the sort for the Catalonian spinning industries. The plus meant an average of 70 pesetas per week (11.71\% of the total cost).

19 In addition to the presence, in Sabadell and in certain professions, of adolescents and elderly people with lower retributions, the determining factor is found in the absence of women in the textile factories of Alcoi. Alcoi's selfacting mules were used by seven men while it was women, on the same number, who did this work in Sabadell. The subordination of the female workers was so evident that, on the one hand, the woman in charge in Sabadell depended on the man responsible for the carding machine, and, on the other, no other hierarchy could be detected among women. On the contrary, in Alcoi there is a person responsible for the self-acting mules and for three different categories of workers. In fact, the inexistence of job ladders is one of the characteristics of feminized sectors (Gálvez, 2006a).

${ }^{20}$ Alcoi's female workers focused their work supply on the knitting, smoking paper and matches industries. We have a remarkable contemporary example of the lesser negotiation capacity of the female labor force. A document from 1935 informs us of an agreement between an employer and his female workers (serge and blanket weavers) by which they accepted a salary reduction in order to avoid that the employer moved to another town looking for workers eager to accept lower salaries and worse working conditions. ATA, 9.16: "Acuerdo entre obreras", November 3, 1935.
} 
Although this higher resistance capacity was not translated into better living conditions for the members of the working class in Alcoi ${ }^{21}$, it seems evident that it allowed the textile workers to maintain a greater portion of the produced surplus. This circumstance, reached after decades of union struggle and thanks to, as well, the particular industrial structure of the town and its area of influence, led -although along different lines sustained more on conflict than on cooperationto a similar situation to that observed by Huberman in cotton-producing Lancashire. The power of the unions in Alcoi imposed, for example, the distribution of work in the hard conditions of the 1930s depression, avoiding the entrepreneurs' temptation of massive dismissals. In a similar way, it allowed the textile workers to enjoy a higher participation in the benefits of productivity derived from technical changes and changes in labor organization. Without considering these circumstances, we could hardly understand the revolutionary collectivization impulse and its peculiar local characteristics.

\section{Collectivization during the Spanish Civil War. The Alcoi textile firms ${ }^{22}$}

The business organization of production was different in the two areas of Spain involved in the conflict since 1936. In general terms, the organization of production on the camp loyal to the Republic was characterized by collectivization and the workers' control of the firms. When workers got back to their jobs after the first days of fighting, they found that many of the factory owners had run away and they took in charge the production in the factories. In doing so, they intended to start a revolution and become production soldiers aiming to defeat the Fascist troops. However, collectivizations were not widespread in the whole of the Republican territory, especially in the Basque Country, where the business network remained based on capitalist relationships and control stayed in the hands of the employers. In addition, many of the collectivized firms eventually became state-owned. In any case, collectivized industries transformed their production according to the war demand, and thus the shoe industry produced boots for the army, the toy industry was transformed to produce knives, cartridges, caps and suits for the militia, and the wood industry produced boxes for ammunition or butts for rifles (Gálvez, 2006c).

On the rebel camp, the industry was militarized and, when the labor legislation of the Republic was dismantled, asymmetric labor relations were established in all sectors so that workers had no means to claim for their rights or have access to collective bargaining. This meant that the labor factor was intensified, something which helped to increase the war production. The most extreme example of this submission exerted on workers was the forced labor conditions in the battalions of prisoners. Labor camps were established in both areas, but only on Franco's side

\footnotetext{
21 This fact proved evident in the comparative study published by the Institut Industrial de Terrasa (Industrial Institute of Terrassa): Estudi de fluctuacions de diversos factors econòmics relacionats amb la vida industrial de Terrassa, 1934 (ATA, 26.3). It is necessary to underline that the explanation of the differences in the life standards of the working families in Alcoi when compared to those of Terrassa (a Catalonian town neighbor to Sabadell which shares identical characteristics regarding its industrial structure) does not lie in their respective negotiation power but, basically, in the specialization of the Catalonian wool sector, which enjoyed a higher and more regular demand (with lower salaries but with more stable occupation and, therefore, higher income in the longer period).

22 Although others have done it from different perspectives, we are not the first to approach this issue. See also Aracil and García Bonafé (1974), Bernecker (1982) and Moltó (1986).
} 
were they organized so that they became true employment offices, massively used for productive rather than military tasks ${ }^{23}$.

In order to understand why the anarchist business organization proved to be successful in the Alcoi textile firms during the Civil War, two aspects must be taken into consideration. One is the bequest from the Employers' Association already described and the second one is war itself. The war was important on two different levels. On the one hand, because the social revolution anarchist and socialist unions wanted to institute in Spain became in some cases a secondary goal after that of winning the war. These unions, the industry needed to be well organized in order to achieve that goal. The Soviet Union's participation on the Republican side worked in this direction, although destroying in certain places the previous, more spontaneous socialist and anarchist organization and, as a matter of fact, it reduced the workers' incentives. Alcoi remained in the hands of the anarchist union not without conflicts with the Republican government. On the other hand, the war's captive demand was essential in order to explain this success, especially because it was precisely on market knowledge and client relations where workers could hardly substitute their former employers. The fact that the whole of Alcoi's textile production was consumed by the Republican army was not an overwhelming problem. In fact, the managers of the collectivization worked very hard together with the Republican authorities in order to restore the channels for the provision of raw material and to place the final productions in their destinations.

\subsection{War, social revolution and collectivization process}

A good business organization is basic to maintain industrial production in a war context. In addition, the negative effects of bad management can be greater the more complex, technically and administratively, the firms are. The industries' reorganization by the socialist and anarchist labor unions was diverse. Organizational differences in collectivizations are explained by the different ideologies that sustained them, by the degree of business concentration in each sector and, most of all, by their being part of a spontaneous movement which included many attempts and experiments and which only later and gradually was legitimized by the government.

There were basically three types of exploitation of those firms managed by the unions. First type: through the workers' control exerted by a board, all operations in the firm were regulated without the need to expel the factory owner; this type was much common in small trade firms. Second type: confiscation, so that the owner transferred its rights to the workers through expropriation, donation or a purchase-sale operation, while he stayed working as a technician, operator or manager in the factory. Third type: socialization or collectivization of all goods (establishment, machinery, raw materials, bank accounts) which were now in the hands of the union, which could also unify the whole industry in a specific town. This meant that the value added, once taxes were deducted and interests and rents paid, passed to the workers as salaries and benefits. In general terms, the units of production confiscated and managed by the workers' boards elected by the unions usually corresponded to those of the old firms, though in certain

\footnotetext{
23 It was Juan García Oliver, a member of the FAI and Minister of Justice, who, through the December 28, 1936 Decree, created the labor camps (Villarroya \& Solé, 1999:257).
} 
cases production was rationalized in order to achieve economies of scale. Thus workshops and factories considered to be non-productive were dismantled, their machinery transferred to other firms economically solvent while these were put under the control of an Administration Board which was responsible before the union and had all the attributions typical of the now extinguished capitalist management system. The latter was the formula adopted by the Alcoi textile industry to face its crisis and to attend the war demand.

Certainly, Alcoi's industry suffered a crisis during the 1930s. It is in this context that we must understand the unification of the paper industry in $1934^{24}$, and that of the metal industry at the beginning of the war. During the conflict, the unions interpreted the pre-war crisis in the textile industry as a boycott of the entrepreneurs against the rise of the unions' power consecutive to the victory of the left-wing government in the general elections of February 1936; the information presented on Table 1 was taken as a basis for this interpretation. ${ }^{25}$

Table 1. Six-monthly Average Sales in pesetas (textile firms)

\begin{tabular}{|l|r|r|r|}
\hline & \multicolumn{1}{|c|}{$\begin{array}{c}\text { Right-wing Period } \\
\text { Period and Date }\end{array}$} & $\begin{array}{c}\text { Left-wing Period } \\
\text { (OA34 -January } \\
\text { (January - July 1936) }\end{array}$ & $\begin{array}{c}\text { Revolutionary Period } \\
\text { (July 1936 - }\end{array}$ \\
\hline Knitwear & $4,760,334.15$ & $2,414,084.25$ & $6,907,190.34$ \\
\hline Woolen cloth & $10,457,559.25$ & $7,721,872.42$ & $13,195,625.48$ \\
\hline Total & $15,217,893.40$ & $10,135,956.67$ & $20,102,815.82$ \\
\hline
\end{tabular}

Source: ATA, Memoria Sindicato de la Industria Textil y Fabril. Comisión Técnica de Control Textil, March 31, 1937.

For the Alcoi Textile Industry and Factories Union:

If we compare the figures of the semestral average in the first and second periods, they will show: for the first one, a normal sale activity, characterized by its good commercial

\footnotetext{
${ }^{24}$ Imitating what the Basque paper industry had achieved when it created Papelera Española (Spanish Paper) -a cartel organization in which Gosálvez, a firm from Alcoi, was integrated-, seven big factories and several workshops and businesses merged in Alcoi in 1934 to form Papeleras Reunidas S.A (United Paper Limited). The new company, with a nominal capital of 60 million pesetas, restructured its production and, at the beginning of 1935, it employed 1.600 workers while its annual production was worth eleven million pesetas (Valero \& Beneito, 1996). Its success represented, doubtlessly, a clear demonstration of the advantages offered by entrepreneurial integration, productive rationalization and an increase in the scale of production. This example surely had a weight on the determination of the Alcoi unions when the collectivization of the textile and metal industries was implemented, as it is somehow manifested in their arguments to justify the confiscation.

25 The Retaliated Workers Reemployment Committee, created after the victory of the Popular Front in February 1936, decided upon 137 cases in the Alcoi textile industry for which 66,621.15 pesetas were paid in terms of indemnity.
} 
zeal, and for the second one, a passiveness only comprehensible as a result of the moment's political influence on those who ran businesses in the textile industry ${ }^{26}$.

The Union ratifies this diagnose by comparing the average of weekly working days from February 16, 1936 to September 14 the same year, the date when the industry was confiscated and unified: 3.5 working days, while from September 1936 to March 1937 the average was 5 working days a week. It is evident that the -captive- war demand was an essential component in the recovery of production, but so it was the unification strategy applied by the unions after the confiscation of the employers' organization in September 1936.

Part of the Civil War historiography has pointed out as a cause for the Republican defeat the lack of business organization, the lack of human capital and cost increases in relation to higher wages due to collectivization and the workers' control of the firms. ${ }^{27}$ The increase in salaries and other specific measures, such as the creation of the Medical Insurance, were the main novelties in the summer of 1936 when the collectivization of the factories had just taken place. There was indeed an increase in the salaries after the workers took control, but this increase was finally settled in a $20 \%$ rise on September 9, 1936. As a matter of fact, it does not seem to be a great problem for commercial benefits since the war demand was higher and there was some inflation in prices during the war. What really meant a heavy mortgage on the collectivized firms was the decision to pay all salaries in case the production was interrupted ${ }^{28}$. However, in Alcoi, the distribution of labor had been established at the time the government changed, in February 1936, but the dynamic war demand made unemployment and the corresponding indemnities unnecessary ${ }^{29}$. It does not seem that medical, retirement or widowhood insurances, as well as the creation of a consumption cooperative and a polytechnic institute that provided technical education -made possible with the business benefits no longer accumulated by the entrepreneurs- were a heavy weight upon the unified firms.

The idea that the lack of human capital was a norm on the Republican camp, representing an obstacle for the good administration of the collectivized firms, has to be linked with the fact that many of the firm managers or owners had escaped, were imprisoned or executed, mainly those related to the bigger companies and those whose names were associated to the existence of difficult labor relations in their firms. Nevertheless, although many of the escaped businessmen took to Franco's area their administration know-how, as well as their capital and business' networks, it seem that the lack of human capital was not the main problem the collectivizations had to face. There are two reasons for this. On the one hand, a lot of businessmen, technicians

${ }^{26}$ ATA, Memoria del Sindicato de la Industria Textil y Fabril. Comisión Técnica de Control Textil, Alcoi, March $31,1937$.

${ }^{27}$ See a review of literature on the topic in Gálvez (2006c).

${ }_{28}$ In the Catalonian cotton industry there were 24 and 25 hours-long working weeks (Bricall, 1969: 64). This multiplied the effects of the problems associated with the supply of raw material. As it has been already mentioned, the financial charge of underemployment was passed from the firms on to the public organizations in Catalonia, but in other firms, such as the Compañía Arrendataria de Tabacos, indemnity payments were made for unemployment (Gálvez, 2006c).

29 "In cases of labor crisis, machinery reduction, innovation or reform no worker will be dismissed, but work will be equally distributed among all workers effective in the factory in those sections directly affected by the crisis, innovation or reform”. ATA, Ref. 34.9, February 1936. 
and supervisors stayed in their business and were alive. In Alcoi they were a majority. Many proprietors of small and medium-size firms remained in Alcoi to control their businesses and in order to collaborate, although works of sabotage by entrepreneurs are also evidenced (Quilis, 1992: 147). On the other hand, the fact that before the war workers participated in factory committees cleared the way for many workers who were already familiarized with the activities of the companies they worked for, thus developing a sense of their own competition. The committees were in charge of the books, assigned tasks and controlled the coordination with other companies and inside the industry. By means of these committees the unions coordinated the whole industry, achieving rationalization through the attainment of economies of scale inside a war economy. When the workers lacked the knowledge needed to carry out administrative or accounting tasks, they usually asked for help to the bank employees that collaborated in the administration management, and so it happened in Alcoi.

\subsection{The anarchist business organization of Alcoi's textile firms}

The organization implemented by the anarchists during the war was a key element to understand the good performance of the different firms which were integrated in that period. The Union, as it was stated in the September 14 declaration by which the Employers' Association was confiscated, considered that few were the factories that would have resisted the first push of the events to follow.

Even though the industry was unified, the partial situation of most factories presented a problem difficult to solve. They only had a stock of raw material valued in 2,401,964.76 pesetas, and more than 50\% of it consisted in remnants and residues roughly prepared to make other products. The blockage of 2,466,180.91 pesetas in the rebel markets hindered an easy development, and the overwhelming charge of 6,944,366.56 pesetas in bank loans made it impossible to have access to new individual loans and resulted in a lack of freedom of action, something absolutely necessary in order to develop ${ }^{30}$.

As a general measure, traders were totally reluctant to attend their payment obligations, and the Union systematically received communications on which their deliberate decision not to pay was made clear. In fact, around March 1937 there were still 2,579,221.72 pesetas in the rebel markets, 6,145,294.76 in loyal Republican markets, 599,863.46 in the local market and $1,276,988.04$ irrecoverable. This happened despite the Union having started, in the summer of 1936, a commercial propaganda service attended by salesmen through commercial offices in those provincial capitals that required it.

With the confiscation of factories, services were centralized that were not so at the beginning of the war but stayed so after Franco's victory. Confiscations and loans solved the first cash-flow problems. With the new funds obtained through the confiscation of machinery, the property states valued in about eighty million pesetas, and a 1,050,000 pesetas loan given by the Revolutionary Committee, the Alcoi Textile Industry and Factories Union was able to start its new path paying off all its previous debts, avoiding bankruptcy protection and the closing-up of firms, using its resources more rationally in centralizing the decision-making process, the purchase of raw materials, orders and distribution. In any case, unification was looked upon as

\footnotetext{
${ }^{30}$ ATA, Ref. 34.9, February 1936, p.12.
} 
the best option to get out of the crisis. The Employers' Association was confiscated as a first and essential step in the process of unifying the industry: "We will proceed to the total confiscation of the Association, for it is understood that, after confiscating the factories, we had to naturally proceed to confiscate the Association in the same terms" ${ }^{31}$.

Alcoi's Textile Union developed an organizational revolution which especially focused on two features: information and the bureaucratic structure. The guidelines for the collection and flow of information were partly imposed by the heads of the Union ${ }^{32}$. Therefore, a complete inventory of the companies at the moment the collectivization started and a daybook of the commercial operations from that date onwards were necessary and indispensable to legalize the usurpations and collectivizations before the local authorities (Quilis, 1992, 22). In fact, unification was not carried out until the following data were collected from all companies: total value of the manufactured goods, number of units of each article, possible weeks in operation with their own resources, amount of credits in areas isolated and cut off because of the war, credit maturities and difficulties, problems with the stocks and solutions proposed. Most of the companies asked for the banks' collaboration on paying back the loans with a moderate interest $^{33}$. The Union kept and organized the original inventories, copying them in a general book, as the information says:

Not all the inventories were real and impartial, some of them showed a situation weaker than the real one, and others tried to improve their future economic situation, and naturally, neither those nor these fit in the spirit of justice and fairness of the Control Commission's performance (...) Once the necessary rectifications were made in the accounting books, the result of the inventories -each firm's amount of assets and liabilities - was formally established (...) No pressure and no circumstance could influence the Control Commission's rules of procedure, because its specific mission was to manage and to run the industry without any personal, political or union guidelines.

This information was the basis for the industry's rationalization and for the unification of orders, sales and credits.

The flow of information and the increase of bureaucratization were essential for an efficient management and organization. And both happened in Alcoi during the process of

\footnotetext{
31 ATA Carpetas de la Asociación Patronal - from July 18, 1936 to September 1936. It was some weeks after the conflict started when the process that had initially flown upwards reverted. In this sense, it is legitimate to question the responsibility of the organizational revolution in the textile industry. In Alcoi, as in many places where Franco's rebellion had not triumphed, the collectivization movement was spontaneous and took place during the first days of the war. Nevertheless, very soon the movement was structured by the leaders of the different unions and by the parties, who dictated measures that legitimized and put those collectivizations under control.

32 In fact, theoretical literature on collectivization always insists on the value of having complete previous information in order to make the best decisions during the revolutionary process. See for example, Piqué (1937). Alcoi's collectivization was a good example of it.

33 ATA, Correspondencia. Official communication between the Industry Delegation in Alacant and the City Council of Alcoi on August 31, 1936. In the answer it is possible to observe that the raw material supply was not an immediate problem but that it soon would be. The lack of liquidity caused by the debts of clients that were in the Nationalist area was a serious problem, the same as the banking credits. This last question was solved through loans and the efficient operation of the unified industry.
} 
collectivization, with the unification of the whole industry and the control imposed on the sector, although that behavior was completely opposite to the one defended by the anarchist ideological program. It became a contradiction that the anarchists had to justify:

After the coup of July 18, (...) the unification and control of the industry were not our goal, even though they are one of our programmatic points because industrial firms do belong to the workers, for we thought it was not the moment to implement this social purpose, but reality pushed us out of improvisation to take the responsibility of controlling the textile and factory industry under such serious circumstances that invited us to consider the effects of our haste. ${ }^{34}$

The explanation given by the organization in the Union's report of May 1937 also shows how a centralized organization and the control of all the productive, financial and commercial aspects were essential for the Union.

(...) The Committee had to modify the system rapidly. There was no way to this democratic model the Committee had hoped for (...) centralization was necessary (...) The Control Committee Office, endowed with more and more assignments and responsibilities, was modified because the circumstances demanded to transform it into a central and general office. Simultaneously, the Control Committee was also transformed according to the complexity of the issues tackled -it was divided into departments that corresponded to Sales, Purchases, Production, Economy and Finances, and there were various Secretaries of the Commission and an Administrative Secretary. ${ }^{35}$

\footnotetext{
34 ATA, Alcoi, December 10, 1938. Ref. 56.17.

${ }^{35}$ ATA, Memoria, 1937.
} 
Figure 2. Reproduction of the organizational structure of the collectivized and unified textile industry.

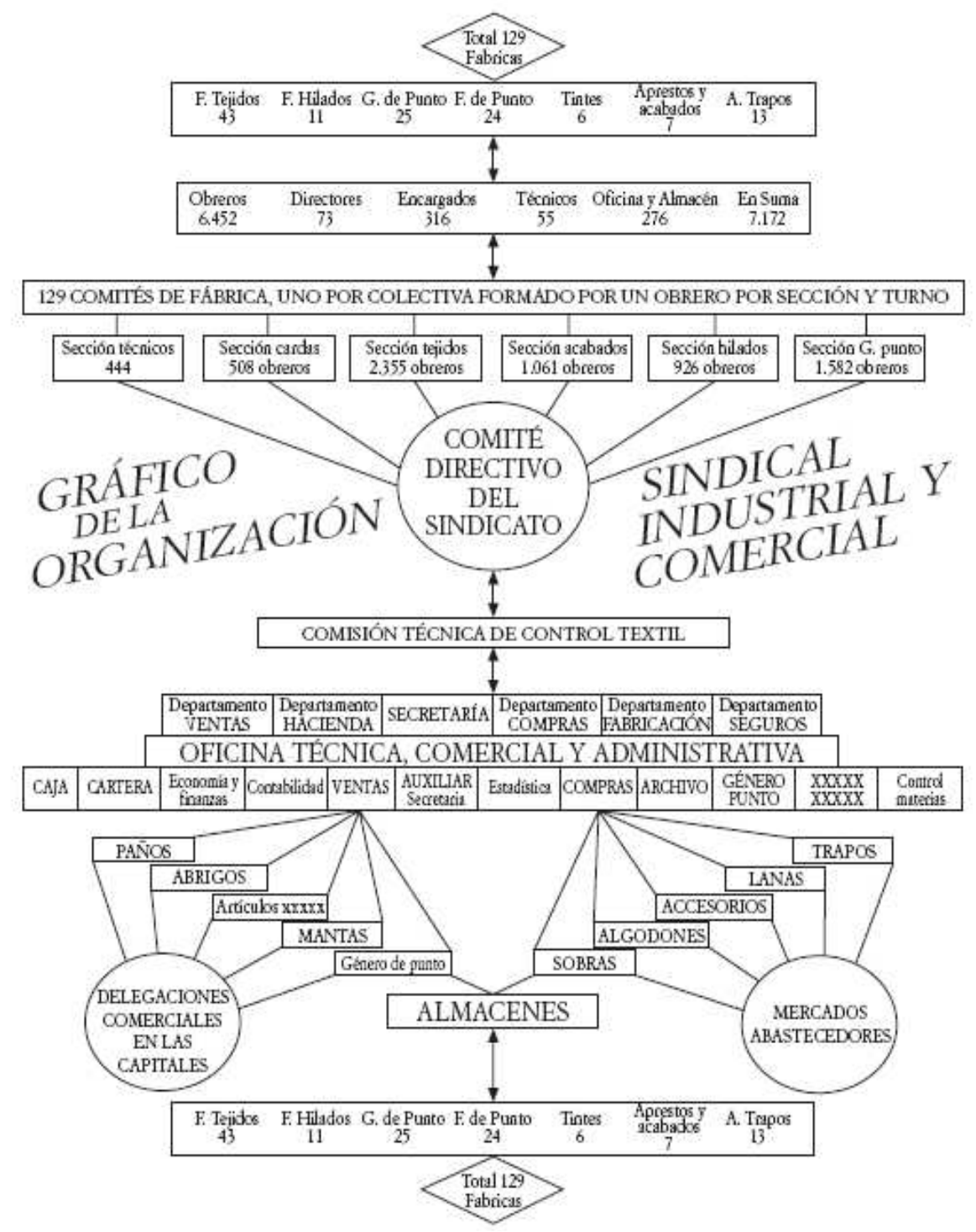

Source: ATA, Memoria Sindicato de la Industria Textil y Fabril. Comisión Técnica de Control Textil, 31-III-1937.

Therefore, the total unification of the 129 collectivized factories shows, on the one hand, that the Union leaders had enough theoretical knowledge on business administration to understand that the most efficient management option was to centralize decisions, and, on the other hand, that they were able to impose their criteria to the rest of the Union. The Union designed a modern managerial structure (Figure 2) on which the company's property did not determine how the production was to be organized, but it was rather the labor force through the action of the Union who actively participated in the administration of the firm. We can observe that the organizational structure had two main parts: an upper one, in charge of regulating the working conditions in the factories and coordinating the workers' assignment in the unified industry, and the lower, responsible for organizing the aspects related with the manufacturing process and the 
commercialization of the final production. As seen in Figure 2, the core organ of the collectivization was the Technical Commission of Textile Control (a kind of Executive Board), composed by the leaders and the technical staff of the Union, who made decisions leaning on several organs with which it had direct relations: on the one hand, the Union's Directive Committee, for those questions related with work organization, and, on the other, the various departments into which the technical functions of the textile industry were divided: Sales, Purchases, Production, Secretaries, etc.

Therefore, the workers were organized by the Union following the indications of the Technical Commission (on which the Manufacturing department used to have a great influence regarding decisions). It assigned the workers depending on the industry's common necessities. In order to do so, and despite the fact that workers generally worked in the same place, those workers who were qualified could be reallocated in other factories or other tasks, according to the collectivization's general necessities or to the war demands. Each factory had as well a Factory Committee (composed by the workers' representatives) that executed the Technical Commission's orders, while it also organized the schedules, resolved conflicts between workers and transmitted their suggestions for the improvement or the escalation of production to the Technical Commission through the Union's Directive Committee. In addition, each factory had a Director named by the Technical Commission whose function was essential for the communication between the head of the industry (Technical Commission) and the workers (Factory Committees). In fact, factory directors -in many cases they were the former owners forced to collaborate with the collectivization; in other cases, they were members of the Union with long experience and a great know-how in this sector- were essential to coordinate the different rhythms of activity in each factory, since often the production process had to stop (when there was lack of raw materials, or energy supply problems, etc.) and an agile organizational answer was required in coordination with the Technical Commission.

Regarding the Technical Commission, the great complexity of the tasks it had to develop led to dividing its functions among various departments like in a big multifunctional firm. The most energetic and active departments were, especially, that of Manufacturing and also those of Purchases, Sales and Treasury. The first one was in charge of designing the day-by-day manufacturing activities, as well as of regulating and organizing the working days during the collectivization process according to the available resources. It also ordered manpower transfers between factories, distributed raw material among them, ordered the stagnation of some sections when the conditions demanded it, organized machine transfers between factories seeking the highest profitability, and finally carried out periodic inspections in the factories in order to check that the whole collectivization process was adjusted to the established plans. Meanwhile, the Departments of Purchases and Sales had to look for solutions to the problems of raw material supplies and to those of placing the final production in its destinations. This was an essential and not always easy task, due, on the one hand, to the communication problems characteristic of a country in war, and, on the other, to the conditions imposed by the banks for the maintenance and administration of current accounts, payment orders, etc. At this point, the work of the clerks and bank employees who were members of the Union was essential as to get the organizational part of the collectivization process in full yield.

Regarding the increase of bureaucracy in the administration, it was a necessary process due to the increasing scale of the unified company. In December 1936 the number of employees of the textile collectivized industry was about 7,172, of which 6,452 were manual labor, 72 directors, 
316 foremen, 55 technicians and 276 clerks and warehouse employees. The high number of clerks explains the quick adoption of the workers' statutes, salary and working conditions rules and, therefore, insurance and retirement regulations. Retributions corresponding to the different professions and working days were established. The unification would not have been possible without the administrative employees' work in the new managerial organization. The increase of office workers shows the organizational change:

Honestly, the organized manual workers were not the most appropriate group to make certain things (...) the first case was the control of the industry and the medical insurance (...) we went to the Center of Trade, Industry and Banking Clerks asking for collaboration for our company; this collaboration was offered by specialized manpower (...) The Technical Commission's operation was not sectarian, as the cooperation of the administrative employees shows (...) Everything was made; every minimal detail was considered in analyzing the industry, and as a result the urgent necessity of unification arose (...) and the Technical Commission of Textile Control had to decide, in a life or death situation for the industry, to decree an intervention through unification, in order to assure and defend the common interests of managers, workers, the people, the local economy, the state and the nation; and, what is most important, to join, to cooperate and to contribute to the war victory that meant the conquest of freedom for everybody (...) the imperative that the situation posed transformed all political programs, all ideologies, all postulates into a common goal, to save the industry, to save Alcoi. ${ }^{36}$

${ }^{36}$ ATA, Memoria, 1937. 
Figure 3. Savings, Currents accounts and Retail Sales
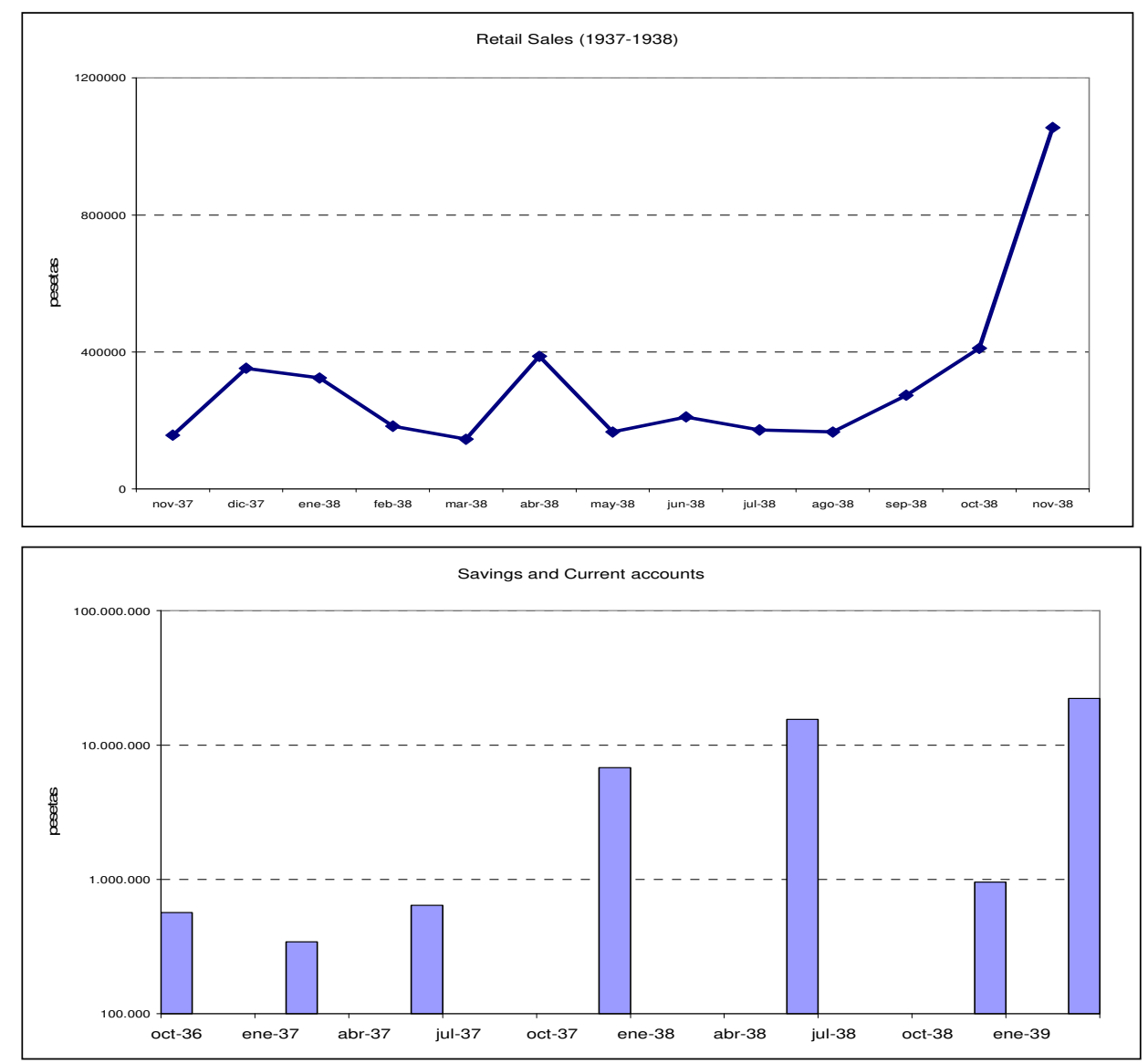

Source: ATA, Memorias.

In this new structure, each collectivized factory could have kept the former accounting system in coordination with the central office, but it turned out to be impossible because a thousand of problems emerged mainly due to a lack of understanding when implementing the procedure; as a result, general chaos brought discredit to the system. For the Union

it was essential to centralize all services, with the positive and well-known results for everybody. This meritorious work done by our colleagues in the administration department needs to be acknowledged (...) All services centralized in a general office, the minimal accounting and statistic details have been attended to, with brilliant works and studies that have deserved congratulations; furthermore, many of them have been appreciated in approbatory verdicts by official centers, as some belonging to the Ministry of Defense. Every collectivization's accounts were incorporated from their individual books into the general Industry Accounts in a scrupulous and detailed fashion; their books of antecedents were classified orderly in appropriate and special places, as were the rest of the documents, invoices, receipts, letters, etc., that conformed the archives of each collectivization process (...) it is necessary to know that in the wide 
structure of our administration a pen, a pencil or any other insignificant object is registered and counted into the corresponding section, be it Consumption, Collective, Warehouse or Office. It is also necessary to know that a simple letter is under the control of five signatures, that of the corresponding secretary and that of the head of department, on the original; and on the copy, the signature of the head of the section, plus the initials of the person who dictates the letter and of the one who writes it down. All operations have to be registered this way. ${ }^{37}$

Despite the restriction of the sources kept in the archives, it is possible to observe an increase in sales, especially after the conquest in the autumn of 1938 of the most important textile centers located in Catalonia. Bank savings also experienced an important increase that permitted the former owners to retrieve their firms and saving accounts but also the benefits achieved by the unified and collectivized firms during the war (Figure 3). As a matter of fact, it does not seem that in the case of Alcoi neither the organization, nor the lack of human capital, nor the high wages meant a problem. The most important concerns in the collectivized industries of the Republican camp were the purchase of raw materials and machinery to start up their factories, and the problem of cumulative stocks and debts which other firms, clients before the war now in Franco's area, had with them ${ }^{38}$. The worst results of the firms located in Madrid - when compared to Catalonian or Valencian companies - can be thus understood. In Madrid, collectivizations were smaller, while market isolation was greater (Catalán, 2006). In the Basque Country there were no collectivizations and it was the region inside the Republican area whose level of industrial production had experienced the most remarkable increment by the time Francos' troops entered its territory. The fact that organization was not a problem during the period of administration of Alcoi's textile industry by the Union is demonstrated through the fact that, when the war was finished and the managers recovered their assets without damages or losses, they kept some centralized services and productive processes the way the Union had created them.

\subsection{War's legacy and the Alcoi textile business network}

Could we talk of success? The Republican side -explicitly defending a different organization of society and the production process which favored labor- lost the war. The organization of production during the war was a key aspect for obtaining a good result. Historiography on the Civil War has always pointed out to the better organization of Franco's camp, both in military and business terms, basically through discipline. However, other aspects such as the international isolation of the Republican government and the internal disputes on the Republican camp are at the root to explain the Republican defeat.

Many collectivizations proved unsuccessful, but they cannot be evaluated independently from the evolution of the Republican army and the Republican territories in general. As it was said at the beginning, the territory that stayed loyal to the Republican government was the most industrialized part of the country. During the 1930s Spain had a relatively highly integrated

\footnotetext{
${ }^{37}$ ATA, Memoria, 1937.

38 See the firm Decoració Textil i Aviació. Archivo Histórico de la Guerra Civil, Leg. 177/3 n²6 (1).
} 
internal market with certain areas specialized in the industrial sector while others basically focused on primary products. While foodstuff was always demanded during the war, that was not the case of many industrial products, especially consumption goods. However, most of those industries transformed their productions in relation to the war demand. In addition to the lack of markets and demand for many of their traditional products, the Republican firms had to face the problems associated to acquiring raw material, something really difficult having in mind the international isolation of the Republican government. In the case of Alcoi, the best proofs of the organizational success of Alcoi's textile firms are two. First, former employers not only recovered their properties and business without physical losses, but they also were able to collect the proportional benefits obtained by the unified and collectivized sector during the war. Second, the degree of the network's integration increased in relation to the years previous to the war-see Figure 1. However, this second outcome must not only be considered a legacy of the war organization, which enjoyed a greater degree of cooperation and property integration than at any other moment in time, but also a consequence of the traditionally cooperative behavior within the industrial district and the adaptive strategies to the new institutional framework established by Franco.

When the war finished in April 1939, the Employers' Association of the Alcoi Textile Industry and Factories regained control of the industry and the project for the separation of the associated companies began. In this process, besides the resumption of control over their factories, the managers gave priority to the recovery of the bank accounts previously confiscated. The Employers' Association played an outstanding role, especially when it defended the individual interests of its members, that is to say, the textile companies. The Unblocking Act of December 7, 1939 returned to the former owners the money corresponding to the bank accounts that belonged to each firm and which the Union had engaged in different banks. But the problems came with another account, the one opened at the branch of the Bank of Spain in Barcelona, whose holder was the Commercial Delegation of the Alcoi Textile Industry and Factories Union and which Antonio Matarredona Pascual, as president of the Employers' Association of the Alcoi Textile Industry and Factories, claimed in July 1940. The existence of an extraordinary deposit in this account fixed the value of the confiscated accounts and offers an indication of the cumulative benefits during the two and a half years of the Union's administration of the industry.

The Employers' Association lodged an appeal to the Unblocking General Commissariat -this organization was created by Franco's government to evaluate and refund the assets of the companies collectivized during the war- that finally was sentenced favorably thanks to the personal contacts of the members of the Employers' Association in Franco's government:

... considering that the justification of the claimant demonstrates that the bank account was opened during the Marxist period by the red elements that confiscated the textile firms of Alcoi operating previous to July 18, 1936, and considering that the incomes of their collectivization and industrial exploitation were registered in such account, without any other assets than those coming from the economic and industrial administration of the usurped companies; this is the reason to consider that the true 
holders of the account are the confiscated firms.... and thus we proceed to the exclusion demanded by the claimant. ${ }^{39}$

The entrepreneurs were clear in their demands. In their opinion there was nothing in the administration of the Union that meant a real innovation and justified the present situation in which they could not have access to the profits as the former and current owners of the factories:

The Union did not contribute to create any new production element other than the usurped ones, neither a patent, brand or manufacturing process, nor an industrial advantage that could be considered beneficial for the industry. It didn't carry out any innovations, in a mere continuation of the former business, with the deprived owner's goods, factories, machinery, etc. The Union leaders, although they received high salaries, made no contribution to compensate for them other than perturbations and changes in the establishment that meant a considerable expenditure when the time arrived to restore the companies to their legitimate owners. It is undeniable in this case, as in the rest of the red affairs, that there was no improvement, not a single new idea to be used ${ }^{40}$

The message the victorious forces meant to transmit was clear, and much less respectful than the lines dedicated to the employers in the documents of the Union, thus showing the class struggle character of the war and the collectivization and restoration processes. But also the fact that the new organizational structure was not acknowledged as an innovation by the employers is remarkable.

Beside the efforts for the restitution of the bank funds, the Employers' Association had to face the core changes brought about by the inauguration of General Franco's regime. The new legal environment had immediate effects in all employers' associations, since the new corporatist legislation forced them to integrate into the structure of Franco's unions. In Alcoi the association made a general change in its denomination and structure in order to escape the direct control of Franco's administration. This way, Textil Alcoyana S.A (A.T., Alcoi Textile Limited) was constituted in 1940. In 1998 it was substituted by the Agrupación Textil Alcoyana (Alcoi Textile Group), operating until today (Terol, 2000). Textil Alcoyana S.A. was a basic network infrastructure, less developed than a technological park or a cluster of firms. The social relationships of the managers or members can also be extended into the public administration and thus favor the whole network, especially if coordination is highly integrated. This is what happened, for example, with the Unblocking General Commissariat's resolution in favor of refunding the collectivized companies' financial assets.

Therefore, the new association was constituted in 1940 as a limited company, with shareholders who were the entrepreneurs-partners themselves, and with an organic structure, which in the following decades would have to adapt itself to the changing features of the political regime. In fact, this initiative responded to the entrepreneurs' interest in the continuation of an institutional framework that kept on working on business cooperation in the industrial district without the need to integrate the firms' property. It is clear that the Alcoi industrial district had a strongly

\footnotetext{
${ }^{39}$ ATA, Carpeta Varios, exp. 51. Alcoi, April 5, 1941.

40 Ibidem.
} 
atomized entrepreneurial structure, with great differences between firms -in size, specialization, vertical integration, etc.- and with a strong personal character based on the firms' historical continuity, since they were all family firms. This feature, which hindered property integration through high opportunity cost -obviously the Union did not take this fact into account-, combined with the long and positive associative experience of previous employers' associations. The degree of complexity and efficiency that the Employers' Association had achieved in the years previous to the war, during the 1930s, could be taken as a model, reinforced by the traumatic experience of recovering the bank accounts and funds blocked by Franco's authorities -the Employers' Association being responsible for the success of the negotiations. This experience could have brought soundness to the organization, engaged again in defending the interests of businessmen cooperatively.

Therefore, the main goal of the A.T. was originally to become the only employers' organization in the sector, assuming those functions on which it had previous experience and offering services to the companies, especially those concerning labor legislation and commitments with the public administration. As the second article of its Statutes said, the goal was "... to facilitate all the Associates the execution of the obligations imposed by the effective laws....". Regarding its structure and financing, the association followed the pattern existing before the war. On the one hand, the company was financed with the members' contribution and, since it was a nonprofit organization, it yielded liability dividends during the first decade of operation. On the other hand, being constituted as a limited society, the company developed an increasingly complex organizational structure -General Board, Board of Administration, Presidency, Treasury, Special Commissions, etc.- adapted through time to the necessities of the associated companies, incurring in a higher degree of coordination similar to that of the war years. In this sense, on the Council's first meeting (1941), the creation of three commissions was approved: the Administrative Commission -that would eventually become the entity's executive center-, the Wool Commission -to manage and negotiate the combined purchasing of raw materials for the partners, according to the share-system which characterized the Spanish industry during the first two decades of Franco's period-, and finally the Exports Commission.

In general terms, to reintroduce business cooperation through the representative organ of the Employers' Association reinforced the mechanisms of mutual trust between textile partnermanagers, especially considering the extremely difficult environment on which production had to be resumed: heavy restrictions on inputs -wool, electric power, oils, etc.-, communication and cash-flow problems, radical transformation of the legal environment, etc. Thus the main tasks of the A.T. during the whole autarchic period, that is, until the mid-1950s, were two: to overcome the obstacles for industrial production, and to collaborate with the public administration in labor and legal matters. Nevertheless, the fact that the entrepreneurs maintained some of the centralized functions -such as the Union previously had- shows certain recognition to the work of the Union, although it was never manifested in the association's documents, considering the present unblocking litigation. In this context, we could present just one favorable testimony, an interview made to a Union leader that some time afterwards said:

The boss that I had later on told me: "what you made was very important, if we had continued in that line, things would not be as bad as they are at the present time' and I answered to him: 'you are the ones responsible for the situation, if only you had wanted to continue, everything was already created and organized'. They had an important capital, 5 millions and a half in goods, 
24 millions in the Bank of Spain, I think also around 36 or 38 in raw materials (Moltó, 1986: 42).

It is clear that the Union benefited from the business of the former owners, thanks to the captive war demand but also to an efficient organization of production, through greater rationalization, an increase in the number of administrative employees and an intense marketing work.

\section{Conclusions}

In this paper we have tried to understand the development of business without a capitalist organization and the role of business networks in such a development. In fact, during the collectivization years the property of the firms and therefore the managers' role and retributions were altered, as was the size of the companies, which were unified to create one single large firm.

In order to understand why the anarchist business organization proved to be successful in the Alcoi textile firms during the Civil War, this article has particularly paid attention to two aspects. One, related to the special conditions developed in the industrial district, mainly the legacy of the Employers' Association, the functions that were already developed collectively before the war and the collectivization process. The second one is war itself.

The war was important from two different angles. On the one hand, because the social revolution that the anarchist and socialist unions wanted to establish in Spain became in some cases a secondary goal after that of winning the war. This means the unions needed to be well organized in order to achieve that goal. The participation of the Soviet Union on the Republican side worked in this direction although it also destroyed in certain places the previous, more spontaneous socialist and anarchist organization and, as a matter of fact, it reduced the workers' incentives. Despite the fact that Alcoi remained in the hands of the anarchist union not without conflicts with the Republican government, this case shows both goals were not incompatible. The organizational design and the administration of the collectivization process is an example of how socialization of the property and (at least partially) democratization of the decisionmaking process in the company were not opposed with rationality and efficiency. On the other hand, the most important aspect in what concerns the war was the captive demand, essential to understand this success. The workers had a weak market knowledge regarding the relationships with the clients. Furthermore -although, thanks to the work of the commercial agents, this did not represent an insuperable obstacle-, the war conditions themselves notably hindered the normalization of commercial relations. However, this was not a serious problem during the war because most of the Alcoi textile production was consumed by the Republican army.

Regarding the firms' collectivization process during the war, this article shows the two main features of the Union's intervention, both of which meant a real organizational revolution of the entrepreneurial network: the flow of information and the process of bureaucratization. Thus, in Alcoi, business profits during the war were not only due to the existence of a captive market, but also to the Unions' efficient organization of the production. This was not the general case, since not all collectivizations had profits. All collectivized firms, as the rest of the companies in the Republican area, had to face the same problems related to the supply of raw material and energy. On the contrary, difficulties linked to disorganization and the scarcity of human capital 
to occupy managerial positions only affected certain companies. If the lack of human capital was not a problem, as it happened in Alcoi, organizational difficulties did not emerge. In Alcoi, most of the managers stayed in the factories and they developed advisory and technical tasks in their collectivized factories. On the other hand, there was an important number of workers with an ample industrial and technical knowledge thanks to their participation in factory committees in the years previous to the war. And finally, the collaboration of bank employees in bureaucratic and accounting tasks was also relevant in order to achieve a centralized production and an increasingly bureaucratic structure. The increment in the number of administrative employees shows this change in the organization. In addition, it is necessary to remember that workers in that period were soldiers of production, not only their families' bread-winners, as they were making a revolution and, most of all, collaborating in the Republican victory.

The exemplary business structure built by the Union shows a high degree of business administration knowledge on the part of the architects of the process. Their success clearly influenced as well the decision of the entrepreneurs to maintain and enlarge the inherited institutional framework of the old Employers' Association of the Textile Industry and Factories of Alcoi (next to the hard economic and institutional conditions of the Spanish post-war period). It is difficult not to explain the growth of services and functions of the Alcoi business network as a collateral result of the collectivization experience, at least partially. This experience, anomalous in that economic context and successful regarding short term results, also demonstrates that a mechanical relationship between the forms of property and those of administration does not work. Collective property in the hands of the workers can be, in the frame of its historical context, as efficient (or, at least in the case here presented, even more) as private property. In this case, the strong organizational tradition and the high politicization of the Alcoi working class allow us to understand the determination in the collectivization process and the efficiency in its design and management. Probably, we are not faced with an anarchist business organization in a strict ideological sense, but it seems unquestionable that the workers demonstrated their capacity to establish a functional and efficient collective business administration.

\section{References}

Aracil, R., \& Garcia Bonafé, M. (1974). Alcoi i la guerra civil: les col-lectivitzacions. Arguments, 1, 23-33.

Becattini, G. (1987). Mercato e forze locali: Il distretto industriale. Bologna: Il Mulino.

Becattini, G., \& Enzo, R. (1996). Sistemas productivos locales y mercado global. Información Comercial Española, ICE: Revista de Economía, 754, 11-24.

Benaul, J. M. (1994). Especialización y adaptación al mercado en la industria textil lanera17501913. In J. Nadal (Ed.), La cara oculta de la industrialización española. La modernización de los sectores no líderes (siglos XIX y XX). Madrid: Alianza Editorial, 199-223.

Benaul, J. M., \& Calvet, J. (2004). The Spanish Wool Industry, 1750-1935. Import Substitution and Regional Relocation. In G. L. Fontana \& G. Gayot (Eds.), Wool: products and markets (13th-20th century). Padova: CLEUP, 854-884. 
Benaul, J. M., Calvet, J., \& Deu, E. (1994). Indústria i ciutat. Sabadell, 1800-1980. Barcelona: Publicacions de l'Abadia de Montserrat.

Bernecker, W. L. (1982). Colectividades y revolución social. El anarquismo en la guerra civil española, 1936-1939. Barcelona: Crítica.

Bricall, J. M. (1969). Algunos caracteres de la evolución de la economía catalana durante la guerra civil española (1936-1939). Moneda y Crédito, 109, 59-94.

Casson, M. C. (1997). Entrepreneurial Networks in International Business. Business and Economic History, 26(2), 811-823.

Casson, M. C. (2009). Networks: A new paradigm in economic and social history? In P. Fernández Pérez \& M. B. Rose (Eds.), Innovation and entrepreneurial networks in Europe (pp. 14-40). New York: Routledge.

Catalán, J. (2006). Guerra e industria en las dos Españas, 1936-1939. In P. Martín-Aceña \& E. Martínez Ruiz (Eds.), La Economía de la Guerra Civil. Madrid: Marcial Pons, 161-227.

Cerdà, M. (1980). Lucha de clases e industrialización. La formación de una conciencia de clase en una ciudad obrera del País Valencià, 1820-1873. València: Ed. Almudín.

Cerdà, M. (1996). Transformaciones económicas y sociales. In F. Moreno (Ed.), Historia de l'Alcoià, el Comtat y la Foia de Castalla. Alacant: Editorial Prensa Alicantina, 625-636.

Cohen, I. (1985). Workers' control in the cotton industry: A comparative study of british and american mule spinning. Labor History, 26(1), 53-85. https://doi.org/10.1080/00236568508584785

Colli, A. (2002a). Family Firms in Comparative Perspective', in F. In F. Amatori \& G. Jones (Eds.), Business History Around the World at the Turn of the Century. Cambridge New York: Cambridge University Press, 339-352.

Colli, A. (2002b). The History of Family Business, 1850-2000. Cambridge: Cambridge University Press.

Colli, A., Pérez, P. F., \& Rose, M. B. (2003). National Determinants of Family Firm Development? Family Firms in Britain, Spain, and Italy in the Nineteenth and Twentieth Centuries. Enterprise and Society, 4(1), 28-64. https://doi.org/10.1017/S1467222700012441

Colli, A., \& Rose, M. B. (2008). Family Business. Oxford: Oxford University Press.

Cuevas, J. (1999). Los orígenes financieros de la industria de Alcoi (1770-1900). Universitat d'Alacant.

Cuevas, J. (2002). Banking Growth and Industry Financing in Spain during the 19th Century. Business Histor, 44(1), 61-94.

Fontana, G. L., \& Gayot, G. (2004). Wool: products and markets (13th-20th century). Padova: CLEUP.

Gálvez, L. (2006a). Challenging a gender neutral business history. Imprese e Storia, 34, 269294. 
Gálvez, L. (2006b). Los mercados de trabajo en la España del s.XX. In A. González-Enciso \& M. B. J. Manuel (Eds.), Historia Económica de España. Barcelona: Ariel, 833-858.

Gálvez, L. (2006c). Produciendo para la revolución y produciendo para la reacción. Trabajo y Guerra Civil, 1936-9. In P. Martín-Aceña \& E. Martínez Ruiz (Eds.), La Economía de la Guerra Civil. Madrid: Marcial Pons, 461-489.

Gálvez, L., \& Cuevas, J. (2001). Technical Education, Regional Industrialization and Institutional Development in 19th Century Spain. In European Business History Conference proceedings. Oslo: Oslo-Norwegian School of Management.

Garcia Balañà, A. (2004). La fabricació de la fàbrica. Treball i política a la Catalunya cotonera (1784-1874). Barcelona: Publicacions de l'Abadia de Montserrat.

Gutiérrez-Poch, M. (1994). Tradición y cambio tecnológico: la industria papelera espanyola, 1750-1936. In J. Nadal (Ed.), La cara oculta de la industrialización espanyola. La modernización de los sectores no lderes siglos XIX y XX. Madrid: Alianza Editorial, 341368.

Hirschman, A. O. (1970). Exit, Voice and Loyalty. Responses to Declin inFirms, Organizations, and States. Cambridge (Mass.): Harvard University Press.

Hobsbawm, E. J. (1964). Labouring men; studies in the history of labour. London: Weidenfeld \& Nicolson.

Hobsbawm, E. J. (1984). Worlds of Labour. Further Studies in the History of Labour. London: Weidenfeld Nicholson.

Huberman, M. (1996). Escape from the Market: Negotiating Work in Lancashire. Cambridge: Cambridge University Press.

Jarillo, J. C. (1988). On strategic networks. Strategic Management Journal, 9(1), 31-41. https://doi.org/10.1002/smj.4250090104

Jones, G., \& Rose, M. B. (1993). Family Capitalism. Business History, 35(4), 1-16. https://doi.org/10.1080/00076799300000126

Lazonick, W. (1979). Industrial Relations and Technical Change: The Case of Self-Acting Mule. Cambridge Journal of Economics, III(3), 231-262.

Lazonick, W. (1990). Competitive advantage on the shop floor. Harvard University Press.

López, N., Montes, M., \& Vázquez, C. (2004). La mano virtual: organización en red e innovación. In J. Tascón (Ed.), Redes de empresas en España. Perspectiva teórica, histórica y global. Madrid: LID, 65-81.

Moltó, S. (1986). Una nueva economía. Socialización y colectividades alcoyanas. Alcoi: Papallona.

Oliver, J. (1931). La crisis textil de Alcoy. Alcoi: Imprenta Armiñana.

Piore, M., \& Sabel, C. (1990). La segunda ruptura industrial. Madrid: Alianza Editorial.

Piqué, R. (1937). L'aspecte econòmic-comptable de la col.lectivització. Barcelona: Editorial Bosch. 
Quilis, F. (1992). Revolución y Guerra Civil. Las colectividades obreras en la provincia de Alicante, 1936-1939. Alacant: Diputació d'Alacant.

Reddy, W. (1984). The rise of market cultura. Textile trade and French society, 1700-1900. Cambridge - Paris: Cambridge University Press - Editions de la Maisonde Sciences de l'Homme.

Robertson, P. L., \& Langlois, R. N. (1995). Innovation, networks, and vertical integration. Research Policy, 24, 543-562.

Scranton, P. (2006). Diversity in Diversity: Flexible Production and American Industrialization, 1880-1930. Business History Review, 65(1), 27-90. https://doi.org/10.2307/3116904

Such, J. (1993). La industria textil de Alcoi-Ontinyent: problemas y perspectivas. Alcoi: Juan Such Juan editor.

Terol, R. (2000). La Textil Alcoyana S.A. Historia de una etapa de la Industria Textil de Alcoy (1940-1988). Alcoi: Agrupación Empresarial Textil Alcoyana.

Thomson, G. F. (2003). THOMSON, G. : Between Hierarchies and Markets: the Logic and Limits of Network Firms, Press. Oxford: Oxford University Press.

Tormo, J. (1996). Entre Alcoi i Sabadell. Dues ciutats unides pel textil. Diari de Sabadell.

Torró, L. (1994). Los inicios de la mecanización en la industria lanera de Alcoi. Revista de Historia Industrial, 11(6), 133-142.

Torró, L. (1996). La Reial Fàbrica de Draps d`Alcoi. Ordenances gremials (segles XVI al XVIII). Alcoi: Institut de Cultura "Juan Gil-Albert" https://doi.org/10.13140/RG.2.1.1066.1526

Valero, J. R., \& Beneito, À. (1996a). La II República: Economía, sociedad, vida cotidiana. In F. Moreno (Ed.), Historia de l'Alcoià, el Comtat y la Foia de Castalla. Alacant: Editorial Prensa Alicantina, 661-672.

Valero, J. R., \& Beneito, À. (1996b). La II República: Evolución política y conflictos sociales. In F. Moreno (Ed.), Historia de l'Alcoià, el Comtat y la Foia de Castalla. Alacant: Editorial Prensa Alicantina, 649-660.

Vidal. (1991). Transportes y mercado en el País Valenciano (1850-1914). València: IVEI.

Villarroya, J., \& Solé, J. M. (1999). Mayo de 1937-Abril de 1939. In Víctimas de la guerra civil. Barcelona: Temas de Hoy, 277-406.

Wilson, J., \& Popp, A. (2003). Industrial Clusters and Regional Networks in England, 17501970. Farnham: Ashgate. 